\title{
Knowledge, Attitude and Practice of Bird Sellers on Avian Influenza Control Program in Bird Markets
}

\author{
Ardilasunu Wicaksono \\ Division of Veterinary Public Health \\ and Epidemiology, Department of \\ Animal Infectious Disease and \\ Veterinary Public Health \\ Faculty of Veterinary Medicine, IPB \\ University (Bogor Agricultural \\ University) \\ Bogor, Indonesia \\ vetsunuedu@gmail.com
}

Abdul Zahid

Division of Veterinary Public Health and Epidemiology, Department of

Animal Infectious Disease and

Veterinary Public Health

Faculty of Veterinary Medicine, IPB

University (Bogor Agricultural

University)

Bogor, Indonesia

abdulzahid_ilyas@yahoo.com

\author{
Chaerul Basri \\ Division of Veterinary Public Health \\ and Epidemiology, Department of \\ Animal Infectious Disease and \\ Veterinary Public Health \\ Faculty of Veterinary Medicine, IPB \\ University (Bogor Agricultural \\ University) \\ Bogor, Indonesia \\ chaerulbasri@gmail.com
}

\author{
Etih Sudarnika \\ Division of Veterinary Public Health \\ and Epidemiology, Department of \\ Animal Infectious Disease and \\ Veterinary Public Health \\ Faculty of Veterinary Medicine, IPB \\ University (Bogor Agricultural \\ University) \\ Bogor, Indonesia \\ etih.sudarnika@gmail.com
}

Abstract-Indonesia is avian influenza endemic area since the first case in $\mathbf{2 0 0 3}$ in West Java Province and had been quickly spread to other areas including Jakarta as the Capital City of Indonesia. Jakarta became the center of attention from the government to control avian influenza due to high population of bird and its interaction with human. This study was aimed to measure knowledge, attitude and practice of bird sellers and to identify the factors toward avian influenza control program on avian influenza in bird markets. Data were collected from bird markets in Jakarta. Data were analyzed to determine associations between these variables using logistic regression analysis and odds ratio. From the result, the sellers had $14.7 \%$ of poor knowledge, $17.3 \%$ of negative attitude, and $10.7 \%$ of poor practice. Moreover, the variable of age, education, training, knowledge and attitude correlate significantly with practice $(\mathbf{p}<\mathbf{0 , 0 5})$. On the other hand, logistic regression analysis revealed that low education compare to high education has odds ratio $(\mathrm{OR})=5.2(1.5-$ 17.8), poor knowledge compare to good knowledge has $\mathrm{OR}=$ 34.3 (3.2 - 374.1), adequate knowledge compare to good knowledge has $O R=10.7(1.2-95.1)$ and negative attitude compare to positive attitude has $\mathrm{OR}=34.2(2.9-406.1)$. In conclusions, the bird sellers' age, education, training, knowledge and attitude had significant correlation with practice of avian influenza control program.

Keywords - knowledge, attitude, practice, bird seller, avian influenza

\section{INTRODUCTION}

Indonesia is avian influenza endemic area since the first case in 2003 in West Java Province and had been quickly spread to other areas including Jakarta as the Capital City of Indonesia. Live poultry market is the place of interaction between human and poultry which has a high potential as a source of avian influenza virus spread and transmission, not only among poultry but also to human being [1]. Therefore, avian influenza control program in the market is one of the important components regarding avian influenza elimination in Indonesia [2]. Beside the poultry market, the specific bird markets which sell pet/wild birds may also predictable as the source to transmit avian influenza. This is related to the multi-species existence which been sold there, and making it easier to transmit the virus from one bird species to another. This kind of bird market is taking place in Jakarta as the capital city of Indonesia and becoming the major problem for its people. Moreover, Jakarta became the center of attention from the government to control avian influenza due to high population of bird and its interaction with human. Indonesian government has been conducting the avian influenza control program on bird markets through the biosecurity practice. In contrary, the program is facing the obstacle due to the lack of bird seller participation on the program. Hence, the measurement of their knowledge, attitude and practice (KAP) of the program is needed as the baseline information to identify the factor that influence of bird sellers participation on the avian influenza control program. This study was aimed to measure knowledge, attitude and practice of bird sellers and to identify the factors toward avian influenza control program on avian influenza in bird markets 


\section{MATERIALS AND METHODS}

\section{A. Sample}

A cross-sectional study was conducted with the selection of 75 bird sellers as the respondents of this research. Respondents were drawn from four biggest bird markets in Jakarta City. The selection of respondent was carried out by proportional allocation from each bird market and the systematic random sampling was addressed.

\section{B. Data Collection}

Data was collected using structured questionnaires by interviewing the respondents. The components on the questionnaires consist of the respondent's characteristics, knowledge, attitude and practice of biosecurity measures. Pre-test and validity test of questionnaires were done before the questionnaires were used on the field in order to determine the suitability of the questionnaires.

\section{Data Analysis}

The scoring of knowledge, attitude and practice was conducted to measure those components from the respondent. This data was categorized by three levels (poor, moderate and good) and was analyzed using descriptive statistics. Furthermore, data were analyzed to determine associations between variables (respondent's characteristics, knowledge, attitude and practice) using logistic regression analysis and odds ratio.

\section{RESULTS AND DISCUSSION}

\section{A. KAP Measurement of Bird Sellers}

The data showed that more than half respondents $(58.7 \%)$ moderate level of knowledge and the rest of them dominated by poor knowledge $(26.7 \%)$ with few number of good knowledge respondents (14.75). It was indicates that their knowledge about avian influenza control in bird market need to be increased. Same trend with the respondents' attitude whereas the majority of them (61.3\%) had neutral attitude toward avian influenza control program, and lack of them $(17.3 \%)$ had the positive attitude, and still $21.3 \%$ respondents had negative condition of their attitude. Furthermore, their practice related to biosecurity measures for controlling avian influenza was dominated by moderate level $(69.3 \%)$ and few of the respondents $(10.7 \%)$ had good level of practice. Hence, the serious intervention program is needed to increase all respondents' KAP to accelerate their participation on avian influenza control program in bird market. The information about respondent knowledge, attitude and practice is showed in Table. 1.
TABLE I. CHARACTERISTICS OF DOG'S OWNER IN SUKABUMI DISTRICT

\begin{tabular}{|c|c|c|}
\hline Respondent characteristics & $\mathrm{n}$ & $\%$ \\
\hline Knowledge & 20 & 26.7 \\
- Poor & 44 & 58.7 \\
- Moderate & 11 & 14.7 \\
- Good & & \\
\hline Attitude & 16 & 21.3 \\
- Negative & 46 & 61.3 \\
- Neutral & 13 & 17.3 \\
- Positive & & \\
Practice & 15 & 20.0 \\
- Poor & 52 & 69.3 \\
- Goderate & 8 & 10.7 \\
\hline
\end{tabular}

\section{B. The Characteristics which Associate with Practice of} Biosecurity

The research revealed that there was a significant relationship between the respondents' education level, level of knowledge and their attitude to the biosecurity practice as one of avian influenza control program in the market. The result of analysis to determine those associate variables can be shown in Table. 2 .

TABLE II. FACTORS WHICH ASSOCIATE WITH THE PRACTICE OF AVIAN INFLUENZA CONTROL PROGRAM

\begin{tabular}{|l|c|c|c|}
\hline \multicolumn{1}{|c|}{ Variables } & OR & $95 \%$ CI & p value \\
\hline Young age vs old age & 0.5 & $0.2-1.3$ & 0.153 \\
\hline Low educated vs high educated & 5.2 & $1.5-17.9$ & $\mathbf{0 . 0 0 9 *}$ \\
\hline $\begin{array}{l}\text { Small business scale vs big business } \\
\text { scale }\end{array}$ & 4.0 & $0.4-40.2$ & 0.242 \\
$\begin{array}{l}\text { Medium business scale vs big business } \\
\text { scale }\end{array}$ & 4.0 & $0.3-49.1$ & 0.305 \\
\hline Has been trained vs has not been trained & 2.4 & $0.6-10.3$ & 0.241 \\
\hline Poor knowledge vs good knowledge & 34.3 & $3.1-374.1$ & $\mathbf{0 . 0 0 4} *$ \\
Moderate knowledge vs good knowledge & 10.7 & $1.2-95.1$ & $\mathbf{0 . 0 3 4}$ \\
\hline *Significant at p<0.05
\end{tabular}

The first variable that has a significant value on the biosecurity practice was the education level of traders. Traders who had a low level of education got odds/possibility of 5.2 times $(1.5$ - 17.9) to apply poor biosecurity practice compared to traders who had high level of education. The second significant one was trader's level of knowledge which related to biosecurity practice. Traders who had poor knowledge had 34.3 times the odds (3.1 - 374.1) to apply poor biosecurity practice compared to traders who had good knowledge. Moreover, traders who had moderate or sufficient knowledge got 10.7 times the odds (1.2 - 95.1) to apply poor biosecurity practice compared with the traders who had good level of knowledge. The last significant factor was the attitude of traders related to biosecurity practice towards. Traders who had negative attitude about avian influenza got odds of 34.2 times (2.9 - 406.1) to apply poor biosecurity practice compared to the traders who had a positive attitude. From this findings, the increasing knowledge and attitude are needed to encourage bird sellers for the application of biosecurity measures in order to prevent avain influenza spread in the market [3] Those factors can be accelerate with the extension and advisory program [4] from the government and related stakeholders in the market. The 
escalation of their knowledge will raise their positive attitude [5] so that the avian influenza control program will be conducted with the participation of bird sellers as an important stakeholder.

\section{CONCLUSION}

Intervention program is needed to increase all respondents' knowledge, attitude and practice toward avian influenza control program to accelerate their participation on the program in bird market. Furthermore, the increasing knowledge and attitude are needed to encourage bird sellers for the application of biosecurity measures in order to prevent avian influenza spread in the market. Those factors can be improved with the extension and advisory program from the government and related stakeholders in the market. The increase of their knowledge will alter their attitude positively so that the avian influenza control program will be applied successfully and the disease can be well prevented.

\section{ACKNOWLEDGMENT}

The authors would like to express the deepest sense of gratitude to the Colorado State University USA in collaboration with Faculty of Veterinary Medicine, IPB University for the funding of this research.

\section{REFERENCES}

[1] M Ma, T Zhao, S Chen, X Xia, X Yang, G Wang, L Fang, G Ma, M Wu, Y Qian, NE Dean, Y Yang, B Lu, W Cao, Avian Influenza A Virus Infection among Workers at Live Poultry Markets, China, 2013-2016. Emerging Infectious Diseases 24(7):1246-1256 (2018).

[2] Food and Agriculture Organization of The United Nation [FAO], Avian Influenza Control Program in Indonesia: Annual Report (2008).

[3] A Wicaksono, E Sudarnika, C Basri. Biosecurity Condition on Bird Vendors Related to Avian Influenza in Jakarta. Jurnal Sain Veteriner 35(2), 269-276 (2017).

[4] A Wicaksono, M Sudarwanto, Increasing of Milk Quality in Small Scale Dairy Farms in Boyolali through Extension and Advisory for Dairy Farmers. Jurnal Agrokreatif 2(2), 55-60 (2016).

[5] A Wicaksono, AZ Ilyas, E Sudarnika, DW Lukman, Y Ridwan, Knowledge, Attitude, and Practice Study of Dog Owners Related to Rabies In Sukabumi Distric, West Java. Jurnal Veteriner 19(2):230241 (2018). 